\title{
The Traditional and Cultural Practice of Installation Art: A Contextual Study
}

\author{
${ }^{1}$ Najmul KadirKaikobad, ${ }^{2}$ Md. Zafar AlamBhuiyan, ${ }^{3}$ Shahina Parveen, ${ }^{4} \mathrm{Md}$. \\ Shohel Anwarr \\ ${ }^{1}$ Assistant Dean \& Assistant Professor, Department of Fashion Design \& Technology, Shanto-Mariam \\ University of Creative Technology, Dhaka, Bangladesh \\ ${ }^{2}$ Assistant Professor, Department of Fashion Design \& Technology, Shanto-Mariam University of Creative \\ Technology, Dhaka, Bangladesh \\ ${ }^{3}$ Lecturer, Department of Fashion Design \& Technology, Shanto-Mariam University of Creative Technology, \\ Dhaka, Bangladesh \\ ${ }^{4}$ Lecturer, Department of Fashion Design \& Technology, Shanto-Mariam University of Creative Technology, \\ Dhaka, Bangladesh
}

\begin{abstract}
Installation Art has dominated in the end of the $20^{\text {th }}$ century to the mainstream of arts. As Electronic and Digital Technology has developed to be adored with the attraction in artworks. To face a visual art a fundamental and firm component is relation of figure with platform of the works and relation of space with product. Culture plays the special role which will be dominated. In $20^{\text {th }}$ century it has concentrated to the platform of modern arts practice, which is its attribute. But the combination and use of space is very limited in the modern artists. Surprisingly Installation Art is very age old practice in the traditional lifestyle of Bangladesh though it is not considered as art in practice. Staging of straw heaps or drying the pottery utensils in the sun of arrangement the same in the earthen kiln or many other cultural or religious practices may be termed as Installation Art practice in Bangladesh. Nevertheless, many internationally famous artists of Bangladesh are recognized and notified for their Installation Arts which have in fact upheld the country's culture with realistic forms of Arts in the daily life.
\end{abstract}

\section{Introduction}

Installation Art is a wide term applied to a range of arts practice which includes the setting up or configuration of object in space, where the entirety of object and space include the artworks. Installation Art is a form of manufacture and display of artwork rather than a movement or style. In fact,it can be encompassed of traditional and non-traditional media such as painting, sculpture, readymade found objects, drawings or texts. However, 'Installations' space or contents sometimes can be determining its sizes. It may be miniature to huge. Installation art is very much different from traditional art. Over last ten years installation art has become a mainstream of art forms. Installation as a classification for a specific form of art came into use fairly recently; its first use of documentation by the Oxford English Dictionary was in 1969. It was invented in this context, in this reference to a form of art that had arguably existed since prehistory but was not regarded as separate category until mid-twentieth century.

In our writing we will discuss about the importance and role of installation art. Firstly, as like the ancient history of architecture, dance, music, sculpture, 'conceptualization of specialty'- which has also an ancient history.

Secondly, characteristically Installation Art is composed of architecture, sculpture, sound and movement. By this way, Installation Art has a conceive relation with tradition (where a mixed cultured is performed).

Here, we like to make a comparison within the traditional art practice through the culture of Bangladesh and the installation art in practice in the world from the inception to the present time.

\section{Literature Review:}

Sometimes Installation Art is described as 'new art form' which is not the consecutive development of any art form. During the political unrest of Paris in 1968, the fundamental concept of installation art was veloped by Roland Barthe's in his essay, 'The death of the Author' ${ }^{1}$. Roland hurls the challenge with the faith of

${ }^{1}$ The Death of the Author (French: La mort de l'auteur) is a 1967 essay by the French literary critic and theorist Roland Barthes. The essay's first English-language publication was in the American journal Aspen, no. 5-6 in 1967; the French debut was in the magazine Manteia, no. 5

DOI: $10.9790 / 0837-2103041318 \quad$ www.iosrjournals.org $\quad 13 \mid$ Page


'with no provenance from the mind of a genius'. Roland's concept has spread by the historical development. (Barthes, 1977)

The limitless presentation of space by Brancusi ${ }^{2}$, nonfigurative spatial construction of Rodchenko ${ }^{3}$ or 'Gendered Spaces' of Barbara Hepwarth and its interpretation has sided away the attraction of the viewers. The western metaphoric articulation of specialty and colonial culture of western have got the similarity attitude or theoretical sources.

In the language of Bonita Ely 'This growing awareness of conceptualized specialty has completely transformed the lexicon of western art practice'. She further discloses the study of Eastern philosophies evaluation by artists such as Brancusi and Klein ${ }^{5}$, Psychologists such as Jung ${ }^{6}$ and Antonin Artaud's ${ }^{7}$ analysis of exotic drama and ritual, influenced a focus away from concrete materiality, performance and preoccupations with aesthetic conventions of beauty aligned with notions of truth, towards an acknowledgement of the ephemeral, the temporal the embodied uncertainty, flues theobject, the void. That means the growing awareness of conceptual specialty of Western world has changed a lots. The practice of Eastern philosophy of arts as like Brancusi and Klein and as like psychologistAntonin Artaud'sexotic drama and ritual analysis, conventions of aesthetic beauty, the parallelism of truth, harshness of reality have sided away the attentiveness of truth. (Ely, 2009)

According to Bonita Ely, this turn has affected a problematic of construction of epistemological reality that identifies binary opposites to represent truth and totality. The west's exposure to Eastern philosophies such as Taoism and Buddhism has encouraged strategies towards a Cathartic resolution of opposites by discriminating subtle degree of difference that which is in-between-the taboo, the hybrid, the mutable. In Taoism the edge where opposite meet and merge is as significant as the dualistic components as the edge embodies the amorphous primal chaos, the source of creation and creativity. This allows a complexity of dialectic, the assertion of differences within difference a release of the imagination from convention, and established art as a location for catharsis, the irrational, dissent, slippage, disjuncture and transgression. Advances in science and technology have also uncovered the hidden structures and dynamics of matter specialty. (Ely, 2009)

Now we like to look back. Ise is the place of Japan where the God of Shinto (the Sun-god) was believed to be born. The emperor family of Japan is still to be believed that the blood of the Sun-god. Ise Grand temple is divided into two parts. The inner side of the temple is encircled with a wall. It is a thatched roofed temple where there is space. There is an open space near the temple which is as like the real temple. From $7^{\text {th }}$ century it is used to repair near the main temple in every twenty years. There is a replica of the temple in the open space. The cyclic construction of the temple has made a phenomenon of strange change of similarity. This timely consciousness, poetic stream have vital examples of installation artists. (Toshio, 1981)

The mythology of Hinduism of India describes the picture queues of the pre-historic time; which is related with contemporary Hinduism, its origin and the time frame. However, even it is related with the religion and customs of the society. If we visit Vithalatemple of Hampivillage of Karnataka of India we will see the evidence. The Historical 'Kishkindha' is the place which is known for 'Varana' is known as monkey kingdom in Humpi village. These references are available in the epic Ramayana. This temple's artistic work is three dimensional which means many things or to hide something. The corridor of the temple is so mystic that one cannot measure the temple by standing there. The walls' of the temple is and their sculptures are so mystic that it can change once presence easily and that's why if a visitor passes this he will get an endless way. Though it is

(1968). The essay later appeared in an anthology of Barthes's essays, Image-Music-Text (1977), a book that also included his "From Work To Text". (http://en.wikipedia.org/wiki/Death_of_the_Author)

${ }^{2}$ Constantin Brâncuși (February 19, 1876 - March 16, 1957) was a Romanian sculptor, painter and photographer who made his career in France. (http://en.wikipedia.org/wiki/Constantin)

${ }^{3}$ Aleksander Mikhailovich Rodchenko (23 November 1891 - December 3, 1956) was a Russian artist, sculptor, photographer and graphic designer. He was one of the founders of constructivism and Russian design; he was married to the artist Varvara Stepanova. (http://en.wikipedia.org/wiki/Alexander_Rodchenko)

${ }^{4}$ Bonita Ely (born 1946) is an Australian multidisciplinary artist who lives in Sydney. Ely established her reputation as an environmental artist in the early 1970s through her work on the Murray Darling Rivers. (http://en.wikipedia.org/wiki/Bonita_Ely)

${ }^{5}$ Klein works for the Briddge Group providing financial and legacy planning for collectors. He was the first executive director of the Chicago ART Project. From 2004-2008 he was the art curator for the 2,500,000-square-foot (230,000 $\left.\mathrm{m}^{2}\right)$ expansion of McCormick Place, the editor of ArtLetter, and wrote for "Chicago Life" which was distributed regionally in the New York Times. (http://en.wikipedia.org/wiki/Paul_Klein)

${ }^{6}$ Carl Gustav Jung was a Swiss psychiatrist and psychotherapist who founded analytical psychology. His work has been influential not only in psychiatry but also in philosophy, anthropology, archaeology, literature, and religious studies. He was a prolific writer, though many of his works were not published until after his death. (http://en.wikipedia.org/wiki/Carl Jung)

${ }^{7}$ Antoine Marie Joseph Artaud, better known as Antonin Artaud (4 September 1896 - 4 March 1948), was a French playwright, poet, essayist, actor, and theatre director. (http://en.wikipedia.org/wiki/Antonin Artaud) 
very miracle that pillars of the temple make some sound waves if touches, it is fact. In the same time the temple is a music box, a sacred place. However we can say the religious importance of a space, its sculptures, sound, dance and customs help a person to the spiritual world which is pre-condition of the contemporary installation art. $(\mathrm{T}, 2011)$ Now we will look at $20^{\text {th }}$ century. In 1916 Dadaism $^{8}$ movement started at Zurich. Dadaism has spread whole Europe and America gradually. Dadaist artists are the founders of installation art. Especially Marcel Duchamp ${ }^{9}$ (1887-1968) is the precursor of this. His most famous installation art is, 'Bicycle Wheel' (1951). Idea of installing idea and the material in relation to the idea to execute the idea of concept was bases on Dada sensibility or Dadaist philosophy. Art is not product in Dadaism. It was the idea of neglecting the gallery culture or denying the gallery culture of buying and selling process. Pictures are counted as products. Product value is considered more important than aesthetic value of a picture. In one sense it can be said that gallery is a shopping center where pictures are sold or purchased. Dadaism has neglected this issue. So, they have advanced in this way that none can purchase the picture only but the whole thing if necessary. (Huelsenbeck R, 1989)

According to the German artist Christopher Bauder ${ }^{10}$ is to diminish the bad all issues. Say Hilter has declared fighting from the German assembly (parliament building) and therefore Christopher has covered the assembly with black clothing. His concept is if we cover up huge space than there will be an environment. And by this way the story of installation begins.

There are some international installation artists:

1. Lygia Clark (1920-1988), Brazilian

2. Jesus Rafael Soto (1923-) Venezuelan

3. Edward Kienholz (1927-1994), American

4. Robert Irwin (1928-), American

5. Sol Lewitt (1928-), American

6. Dan Flavin (1933-1996) American

7. Ben Vautier (1933-), Swiss

8. Hans Haacke (1936-), German

9. Robert Smithson (1938-1973), American

10. Judy Chicago (1939-) American

11. Vito Accomei (1940-) American

12. Michael Heizer (1944-) American

Here we are going to discuss about Michael Heizer ${ }^{11}$ and his artworks. In the mid sixty when Michael Heizer was busy for the drawing of huge negative paintings in New York. From that time, he used to visit Nevada and California to make the research with canvas in the large American desert. There he has created the negative sculpture. That Genre which Michael Heizer and his associate Walter De Maria have invented and termed as 'Earth art' or 'Land art' which has changed the history of modern art. In the limitation of gallery and museum Michael Heizerhas greatly worked for shape and related other things related sculpture with design. His work is as like a three dimensional lexicon.

Michael Heizer's first negative artwork was in 1967 North, South, East and West. In which he used wood and sheet metal. At present this work is at Beacon's Dia Musuemas a permanent resource. Michael Heizer, in fact has worked with components and shape. This huge expanded sculptured component in a cubic form forms a different look. A big and a small cubic form marked 'North' a cone is for 'South', a three dimensional trough for 'West' and an inverted truncated cone is for 'East'. It is 125 feet height and 20 feet under the floor of the gallery. There was no contemporary works in its time. The architectural value of Michael Heizer,

\footnotetext{
${ }^{8}$ Dadaism was an art movement of the European avant-garde in the early 20th century. Dada in Zurich, Switzerland, began in 1916, spreading to Berlin shortly thereafter, but the height of New York Dada was the year before, in 1915.The term anti-art, a precursor to Dada, was coined by Marcel Duchamp around 1913 when he created his first readymades. Dada, in addition to being anti-war, had political affinities with the radical left and was also anti-bourgeois. (http://en.wikipedia.org/wiki/Dada)

${ }^{9}$ Marcel Duchamp (28 July 1887 - 2 October 1968) was a French, naturalized American painter, sculptor, chess player, and writer whose work is associated with Dadaism and conceptual art, although careful about his use of the term Dada and direct association with Dada groups. (http://en.wikipedia.org/wiki/Marcel_Duchamp)

${ }^{10}$ Christopher Bauder studied in the digital class at the Berlin University of the Arts and graduated in 2003. This is when he started working in the field of interactive installation art and design. For his interactive installation 'Tone Ladder' he received the Newcomer Award "Multimedia Transfer Award". In 2005 he was granted a Berlin Postgraduate Fund to realise his interactive art installation BUGS. In 2004 Christopher Bauder founded the design studio WHITEvoid interactive art \& design. The studio operates at the interface between art, design and technology. Space, object, sound and interaction are the key elements of all works. The installations and products are created for museums, exhibitions and trade fairs, festivals, concerts and nightclubs and gained worldwide recognition. (http://en.wikipedia.org/wiki/Christopher_Bauder)

${ }^{11}$ Michael Heizer is a contemporary artist specializing in large-scale sculptures and earth art (or land art). He currently lives and works in Hiko, Nevada. (http://en.wikipedia.org/wiki/Michael_Heizer)

DOI: $10.9790 / 0837-2103041318 \quad$ www.iosrjournals.org

15 | Page
} 
especially 'Double Negative'12 and city are still going on from the 1970s. That architecture style always recalls the culture of monuments of stone. Michael Heizer's father was an anthropologist. Being the son of an anthropologist he has taken the forms from various ancient sources. But he didn't say these are the formula of his works rather he made the comparison amongst those. Michael Heizer's sculpture is really fantastic. Though it can make in small space, it is not so easy for others. Huge shape and architectural sculpture creates object and atmosphere. Michael Heizer told, "Awe is a state of mind equivalent to religious experience, I think if people feel commitment they feel something has transcended..... think that large sculptures produced in the 60's and 70 s by a number of artists were reminiscent of the time when societies were committed to the construction of massive, significant works of art."

Double Negative by Michael Heizer can be called an Earthwork. It is situated in Nevada in a desert. That was the symbol of time as like Robert Smithson's ${ }^{13}$ 'Spiral Jetty ${ }^{14}$ (1970) and De Maria's ${ }^{15}$ 'The Lightning Field ${ }^{16}(1977)$. The artwork Double negative is divided into two trenches which were cut from the two sides of Marmon Mesa. Sandstone strata and stone have driven away by bulldogger. This space is as like Empire State Building which is comparable with the modern architecture. Thus Michael Heizer's work has made the history. The trench's natural shape has made the open space of $1500 \mathrm{ft}$ length, $30 \mathrm{ft}$ width and $50 \mathrm{ft}$ depth which is made by the excavated of two Lac forty Thousand tons of stones. Though Double Negative was formed by huge earth work but it is not a physical work at all. In fact according to the theory it is made from negative space. Traditionally this is called the volume of the sculpture that was built with emptiness. Double negative was the work for the first time and this artwork is the result of a movement which is called 'land art'. Earth work is a contemporary work of art where the earth is used as the canvas of the work. To maintain the standard the difference between modern art and common goods have disappeared here. One can see how earth is wrapped with art.

In fact 'Double negative' is a construction artwork rather an artwork from where something has removed to make it's an artwork. The art work itself is a negative space which has passed through an empty space. Considering all characters, double negative is an installation art.

About Installation art according to Joseph Beuys ${ }^{17}$, Creativity is not the monopoly of artist. This is the crucial fact that we've come to realize and this broader concept of creativity is my concept of art. When we say everybody is artist, we mean everybody can determine the content of life in his particular sphere, whether in painting, music, engineering, caring for the sick, the economy or whatever. All around us the fundamentals of life are crying out to be shaped or created. But our idea of culture is severely restricted because we have always supplied it to art. The dilemma of museums and other cultural institutions stems from the fact that culture is such an isolated field and that is even more isolated. An ivory tower in the field of culture surrounded first by the whole complex of culture and education and by the media which are also part of culture. We have a restricted idea of culture which debases everything; and it is the debased concept of art that has forced museums into their present weak and isolated position. Our concept of art must be universal and have the interdisciplinary nature Universality, and there must be a University department with a new concept of art and science.

Joseph Beuys, a German famous installation artist comments that, creativity is not the monopoly of artist. This is very vital fact which we have to realize and that wider concept of creativity is the concept of his realization. In fact, everybody is artist in his assumption but it differs man to man which is also a factor of geographical change in the particular subject matters such as painting, music, engineering even caring for the sick. Our idea of culture is different because we always supply it to art. We have a restricted idea of culture that indicates everything that encompasses us. (Ely, 2004)

In the presentation of a paper titled 'Installation Art Paperback' on August 17, 1996 by Nicolas de Olivera, et al emphasized that though installation art is somewhat unsetting and less comfortable. It needs

\footnotetext{
${ }^{12}$ Double Negative is a piece of land art located in the Moapa Valley on Mormon Mesa (or Virgin River Mesa) near Overton, Nevada. Double Negative was completed in 1969 by the artist Michael Heizer. (http://en.wikipedia.org/wiki/Double_Negative)

${ }^{13}$ Robert Smithson (January 2, 1938 - July 20, 1973) was an American artist famous for his use of photography in relation to sculpture and land art. (http://en.wikipedia.org/wiki/Robert_Smithson)
}

\footnotetext{
${ }^{14}$ Spiral Jetty is an earthwork sculpture constructed in April 1970 that is considered to be the central work of American sculptor Robert Smithson. Smithson documented the construction of the sculpture in a 32-minute color film also titled Spiral Jetty. (http://en.wikipedia.org/wiki/Spiral Jetty)

${ }^{15}$ Walter Joseph De Maria (October 1, 1935 - July 25, 2013) was an American artist, sculptor, illustrator and composer. He lived and worked in New York City. Walter de Maria's artistic practice is connected with Minimal art, Conceptual art, and Land art of the 1960s. (http://en.wikipedia.org/wiki/Walter_De Maria)

${ }^{16}$ The Lightning Field (1977) is a land art work in Catron County, New Mexico, by sculptor Walter De Maria. It consists of 400 stainless steel poles with solid, pointed tips, arranged in a rectangular 1 mile $\times 1$ kilometer grid array. (http://en.wikipedia.org/wiki/The_Lightning_Field)

${ }^{17}$ Joseph Beuys (12 May 1921 - 23 January 1986) was a German Fluxus, happening and performance artist as well as a sculptor, installation artist, graphic artist, art theorist and pedagogue of art. (http://en.wikipedia.org/wiki/Joseph_Beuys)

DOI: 10.9790/0837-2103041318 www.iosrjournals.org $16 \mid$ Page
} 
expertise to explain and to synchronize the expression. It needs huge rethinking for the fundamental concept such as authenticity and artists intention, re-examine the commonly treatment procedure and restructured of the division of works. Installation Art accumulates the alternative ground of the artist's thinking. (Nicolas de Oliveira, August 17, 1994)

By the fabulous arguments Kathleen Massara in her paper 'Ann Hamilton Armory Installation Features Swings, 'Pigeons And A Giant White Curtain (PHOTOS)' in 'The Huffington Art \& Culture Magazine' tries to established that Installation Art is the original, vigorous and fertile form of art today. Contemporary art cannot be described without including installation art. It is a rich art form, often heroic in scale, sometimes witty and subversive usually impermanent. (Massara, Ann Hamilton Armory Installation Features Swings, Pigeons And A Giant White Curtain (PHOTOS), 2012)

Ann Hamilton Armory Installation Features Swings, Pigeons And A Giant White Curtain (PHOTOS) Ann Hamilton had set up an installation art on human action named 'the event of a thread' (7 December, 2012January 6, 2013) which included speaking, singing reading and writing of human actions with the poetic potential of physical forces such velocity, time and sound, that is in fact harmonized the exhibition in the month long. In the installation art, combined actions of the human had exhibitedthat indicated the complicacy of art with human daily life.(Massara, Ann Hamilton Armory Installation Features Swings, Pigeons And A Giant White Curtain (PHOTOS), 2012)

Steinkamp, J. (2001) has written in her 'My Only Sunshine: Installation Art Experiments with Light, Space, Sound and Motion' interactive architectural art of installation is a new concept of worldwide. An artist finds a new genre of work with a combined or different language. It's really a refitting existing genre who works with new media creating new language of art form. Her artwork consists of projected interactive computer animation installation. (Steinkamp, J. 2001)

From the write of Jacucci, G., Spagnolliet al (2009) installation art was used in the theater production of 'Galileo Galilei' where the different galaxies of the sky were shown by the projected computers. The motion of the stars, galaxies, their chancing colors and used different types of voices had created a lively presentation of the Universe. (Jacucci, G., 2009)

\section{Findings}

There are many establishments and installations which are spread out inside Bangladesh. For example we can say for the straw heap around any tree, which is used for the fodder on the year round. The same thing is repeated every year in the same way. On the other hand, in the potter's village raw utensils are kept to sundry under the open sky and some are kept to dry after dyeing and burning. In the wedding ceremony different structures are made from papers, jute and banana trees. Different musical instruments are used to create the joyful environment of wedding.

In the religious rituals or in the puja or other religious festival some idols of gods are made for the worship and these idols are decorated with ornaments with offering different fests. There is light work for the idols before sacrifice in the water which may be called religious installation.

There are many installations even within the tribal people of Bangladesh. It will not be an exaggeration that their home making is an installation art. By terracing in the hills they build their houses with bamboos, woods and thatching materials. We got the concept much later after the introduction of Japani installation in the 'Asian Art Biennial'. Artist Hamiduzaman, Aminul Islam, Nisar Hossain, Dhali Al Mamun, Alok Roy and Ashok Karmaker are the famous installation artists in Bangladesh. Artist Mahabubur Rahman, Tayeba Begum Lipi, Syed Azizur Rahman Tarif are the new faces in the installation art. The famous work of Nisar Hossain was in gallery 21 named 'Ekatturer Ghatak' which is a successful installation.

Dhali Al Mamun along with two artists has made a famous installation in the breaking time of 'Gallery Jojon'. His concept was breaking gallery is harmful for art. Dhali Al Mamun's another installation is 'Opap Briddo Jol'- which concept is from the Rangamati submergible land policy enacted by the government by Kaptai dam. There are many installations by Artist Mahabubur Rahman and Tyeba Begum Lipi have done many installation arts. 'Deyalero Kan Achey' is one of the famous works of Tyeba Begum Lipi. 'Vokter Somaje Satter Kata' is a renowned work of Syed Azizur Rahman. In the context, installation art is new but enrichment has come in the art.

\section{Conclusion}

Installation Art is the recognized recent concept as Art in worldwide. Many famous artists have worked on it as art works. There are many well-known installations in the world as it was considered for the monumental structures using the spaces, perspectives and others components of arts. Sometimes huge earthworks even have considered the Installation Art to glorify the artists their names with their works. On the other hand, Installation Art in Bangladesh is somewhat traditional practices with or without consciousness though there are some famous artists have installed many artworks and noted for these works and rewarded from 
some noted organizations. The religious, traditional and cultural practices of Bangladesh are within this art practices.

\section{References}

[1]. Barthes, R. (1977). The Death of the Author. New York: Hill and Wang.

[2]. Ely, B. (2009). Change and Continuity: the Influences of Taoist Philosophy and Cultural. University of Western Sydney, Sydney.

[3]. Huelsenbeck R, R. M. (1989). En Avant Dada: A History of Dadaism. Cambridge, Mass, London: Belknap Press of Harvard University Press.

[4]. http://www.academia.edu/8093481/The_Ancient_History_of_Installation_Art.

[5]. Jacucci, G., Spagnolli, A., Chalambalakis, A., Morrison, A., Liikkanen, L., Roveda, S., \&Bertoncini, M. (2009). Bodily explorations in space: Social experience of a multimodal art installation. In Human-Computer Interaction-INTERACT 2009 (pp. 62-75). Springer Berlin Heidelberg.

[6]. Massara, K. (2012). Ann Hamilton Armory Installation Features Swings, Pigeons And A Giant White Curtain (PHOTOS) . The Huffington Art \& Culture

[7]. Nicolas de Oliveira, N. O. (August 17, 1994). Installation Art Paperback. Smithsonian Institution Press.

[8]. T, D. (2011). A STUDY OF THE SONGS OF PURANDARADASA IN THE SOCIAL HISTORICAL AND RELIGIOUS CONTEXT OF VIJAYANAGARA EMPIRE 1485-1564A.D. Pondicherry University, Department of History.

[9]. Toshio, K. (1981). Shinto in the History of Japanese Religion. Osaka University.

[10]. Steinkamp, J. (2001). My Only Sunshine: Installation Art Experiments with Light, Space, Sound and Motion. Leonardo, 34(2), 109112 . 